\title{
The Development of Teachers' Career in Relationship to OCB and Justice: A Study in Malaysia
}

\author{
Ummi Naiemah Saraih ${ }^{1}$, Hassan $\mathrm{Ali}^{1}$ \& Shaiful Annuar Khalid ${ }^{1}$ \\ ${ }^{1}$ School of Business Innovation and Technopreneurship, Universiti Malaysia Perlis, Jalan Kangar-Alor Setar, \\ Kangar, Perlis, Malaysia \\ Correspondence: Ummi Naiemah Saraih, School of Business Innovation and Technopreneurship, Universiti \\ Malaysia Perlis, Jalan Kangar-Alor Setar, 01000, Kangar, Perlis, Malaysia. Tel: 60-17-608-0656. E-mail: \\ ummi@unimap.edu.my
}

Received: February 4, 2015 Accepted: March 14, 2015 Online Published: August 18, 2015

doi:10.5539/ass.v11n24p62 URL: http://dx.doi.org/10.5539/ass.v11n24p62

\begin{abstract}
This study is conducted to examine the relationship between organizational citizenship behaviour (OCB) and teachers' Career Advancement (CA) in the context of the Malaysian teachers. Two aspects of teachers' CA such as number of promotion (NOP) and career satisfaction (CS) have been investigated in this study. This study also explores the roles of justice (distributive justice, procedural justice, interactional justice) as moderator in the relationship between OCB and CA. The data was gathered through mail survey method from 390 respondents. First, the result showed that OCB was not significantly related to NOP as well as to CS. Second, this study found that all factors of justice were the predictor to CS but not to NOP. The results also found that there was a significant interaction between OCB and distributive justice to NOP and CS. This study contributed some new knowledge which can be channeled to the Ministry of Education (MOE) to improve the level of OCB, justice and teachers' CA, particularly in the Malaysian context.
\end{abstract}

Keywords: career, OCB, justice, teacher

\section{Introduction}

\subsection{Introduction}

There are several reasons for the growing interest in career research. Given that, the present study explores one of the most current research topics that is, CA. As defined by Zhao and Zhou (2008) CA is one of the objectives that all employees are looking forward throughout their career. Based on the existing literature, there are two types of CA which can be categorized as the extrinsic and intrinsic career. Previous researchers acknowledge that the extrinsic CA comprises several visible outcomes such as pay, promotion and ascendancy. Meanwhile the intrinsic CA comprises several invisible outcomes such as CS, life satisfaction and job satisfaction.

Apart from that, an important dimension which may be taken into consideration in the performance appraisal process is termed OCB (Christensen \& Whiting, 2009). Since Grubb (2007) stated that performance appraisal may provide the basis for pay and promotion; hence it would have very much effect toward employees' rewards and career path (Yee \& Chen, 2009). DiPaola, Tarter and Hoy (2004) call for a study to look on how OCB may be rewarded in the school context. Thus, the researcher tries to add some new knowledge regarding the relationship between $\mathrm{OCB}$ and $\mathrm{CA}$. The core business for the Malaysian teachers is to engage them with teaching and learning (Malakolunthu \& Malek, 2008). The Malaysian teachers are also expected to guide students to behave into good moral behavior (Mohd Shahrom, 2009). Given that, the Malaysian teachers are expected to demonstrate the voluntarily behaviours or OCB that are not formally part of their job. Hence, this study tries to fill in the gap on how OCB may be rewarded to teachers particularly in the Malaysian context.

Moreover, this study intends to contribute to the current literature by including organizational justice (OJ) as a moderator in the relationship between OCB and CA. To demonstrate support to the proposed moderator, this research needs to show the relationship between OJ and the predictor variables (OCB), as well as the relationship between $\mathrm{OJ}$ and the criterion variable (CA). In general terms, a moderator is a qualitative or quantitative variable that affects the direction and/or strength of the relation between an independent or predictor variable and a dependent or criterion variable (Baron \& Kenny, 1986). Therefore, this study attempts to examine the influence 
of teachers' OCB on NOP (e.g. extrinsic CA) and CS (e.g. intrinsic CA). Next, the role of OJ as a moderator has been investigated in this study.

\subsection{Career Advancement (CA)}

Examinations of several empirical works reveal several predictors of CA such as gender roles (Akhtar, 2010), mentoring (Okurame \& Balogun, 2005), career commitment (Ballout, 2009), acquisition of social capital (Metz $\&$ Tharenou, 2001), and upward influence tactics (Zainal, 2009). Several scholars (Bergeron, 2005; Carmeli, Shalom, \& Weisberg, 2007) propose the factor of OCB as a predictor of individuals' CA. However, there were inconsistent link between the relationship of OCB and CA based on the previous studies. For example, Bergeron (2005) finds that four dimensions of OCB (e,g. research OCB, advising OCB, professional service OCB, service $\mathrm{OCB}$ ) are positively and negatively related to CA (e.g. promotion, speed to CA). However, Carmeli et al. (2007) present that there are no significant relationship between OCB (e.g. altruism, compliance) and CA (e.g. career mobility, promotion prospect). Therefore, the inconsistent results regarding the relationship between OCB and CA do not permit much knowledge to the existing literature. Thereby, it warrants a further empirical examination.

A few empirical investigations addressing individuals' CA have been reported in Malaysia (Malakolunthu \& Malek, 2008; Mohd Shahrom, 2009). However, there is still lack of knowledge regarding the effect of OCB on both categories of individuals' CA. As reported in Harian Metro (30 September 2010), the Malaysian teachers are responsible to manage the works regarding curriculum and co curriculum. They are also expected to give the extra cares in guiding students not only during the school hours but also after school. Hence, it may means that teachers need to perform beyond the official role of their duty, or OCB. This means that task performance alone may not be enough for teachers to fulfill their job requirements. Therefore, some works such as OCBs (e.g. stay after school hours to help students with class materials) require them to perform beyond the formal job requirements.

According to DiPaola et al. (2004), teaching is a complex activity that requires professional discretion. Thus, OCB is a useful term to describe voluntary teachers' behaviours that go the 'extra mile' to help students and colleagues. OCB is essential because schools cannot anticipate through formally stated in-role job descriptions for achieving goals. The core business for the Malaysian teachers is based on teaching and learning (Malakolunthu \& Malek, 2008). However, the Malaysian teachers are often expected to be dynamic in action as resource managers, facilitators of learning and guide to good moral behavior (Mohd Shahrom, 2009). Given that, teachers' roles may not limit to perform the core business such as teaching and learning (e.g. task performance) since teachers are also expected to guide students to behave in good manners during and after school (e.g. OCB). Since DiPaola et al. (2004) call for a study to look on how OCB may be rewarded in the school context, the researcher tries to add some new knowledge regarding the impact of OCB on CA.

In Malaysia, several empirical investigations supported that there were dissatisfactions regarding teachers' CA. Muda and Omar (2006) stated that the issue of job satisfaction became important. It received a lot of complaints particularly in terms of teachers' promotion. Most teachers claimed that their salary was quite low and promotion under MOE was quite limited (Mohd Shahrom, 2009). Existing literature suggests that OJ will enhance teachers' satisfaction in performance appraisal. Teachers' performance appraisal provided the basis for teachers' career under MOE. Thus, this leads to the assumption that the presence of OJ will enhance teachers' satisfaction in their career outcomes as well. Empirical evidence suggests that employees who perceive higher level of justice tend to demonstrate more OCB. Thus, this study proposes that higher level of justice may increase the level of teachers' OCB. Hence, this study is carried out to examine the impact of OCB on CA, particularly in the context of the Malaysian teachers. In addition, the role of OJ as a moderator had been tested in this study.

\subsection{Organizational Citizenship Behaviour (OCB)}

Over the past decade OCB research has received considerable attention because of the good impact of OCB that is believed can contribute to major success towards organization effectiveness and functioning (Podsakoff, MacKenzie, Paine, \& Bachrach, 2000). Research on OCB has produced some interesting insights in organizational setting, but until recently the concept has been neglected in the study of schools (DiPaola \& Hoy, 2004). Most of OCB studies prefer to focus on employees who work in a commercial setting such as hotels (Khalid \& Ali, 2005), banks (Karatepe \& Uludag, 2008) and manufacturing industries (Hsieh \& Hsieh, 2003) rather than employees who work in a non-commercial setting such as schools. OCB research in schools is still limited (DiPaola \& Tschannen-Moran, 2001). Thus, this study would like to contribute some information on the consequences of teachers' OCB especially in the Malaysian schools. Therefore, this study is designed to examine whether OCB may create any impact on teachers' CA in the Malaysian context. Teachers' OCB may include 
extra effort to make lessons enjoyable and interesting, organizing extra-curricular activities and spending personal time talking with students.

However, there are two potential problems in studying OCB in the educational context. Therefore, the construct of teachers' OCB needs to be carefully operationalized (Hannam \& Jimmieson, 2002). The study of OCB in teaching and other helping professions has largely been ignored. This may be because OCB is defined as helping behaviours, which makes it difficult to determine which behaviours in the helping professions are 'extra role'. As such, the construct of OCB in the teaching profession first needs to be clearly identified and unambiguously operationalized. It was not only important to categorize the various types of OCB but also to determine the level at which OCB is aimed (e.g. organization, team members, or students). OCB pitched at different levels may be motivated by different factors (Hannam \& Jimmieson, 2002).

Thus, in this study the single dimension of teachers' OCB is used. OCB in school context benefits the organization, the team members and students as well (DiPaola et al., 2004). Therefore, OCB in school have been combined into a single construct. To this end, the single dimension of DiPaola et al. (2004) OCB in school scale has covered the levels at which OCB are aimed including the organization, the team members and the students. OCB is a useful term to describe voluntary teachers' behaviours that go the 'extra mile' to help students and colleagues to succeed; and that are not performance expectations of their official role (DiPaola et al., 2004).

\subsection{Organizational Justice (OJ)}

OJ appeared as an important construct in the Industrial-Organizational psychology in the last decade. OJ is defined as an individual's perception of and reactions to fairness in an organization (Greenberg, 1987). As stated by Cropanzo (1993) OJ is referred to the fair and ethical treatment of individuals within an organization; with many confusing terms and distinctions. In broad terms, OJ refers to perceived fairness of interactions between employees and the organization (Colquitt, 2001). Hence, OJ is conceptualized as a multidimensional construct. The first dimension of OJ is termed distributive justice. Distributive justice is referred by Folger and Greenberg (1985) as the perceived fairness or equity of the manner in which rewards are distributed in organizations.

The second dimension of OJ is known as procedural justice. As stated by Leventhal (1980), procedural justice is defined as the fairness of the processes that leads to outcomes. When individuals feel that they have a voice in the process or that the process involves characteristics such as consistency, accuracy, ethicality, and lack of bias then procedural justice is enhanced. Later, Leventhal and his colleagues (Leventhal, Karuza, \& Fry, 1980) redefined the previous definition of procedural justice and referred procedural justice as the fairness of the formal or structural process by which an allocation decision is determined. However, other scholars (Folger \& Greenberg, 1985) stated that procedural justice is referred to the perceived fairness or equity of the procedures used in making decisions regarding the distribution of rewards.

The third type of justice is referred as interactional justice. According to Bies and Moag (1986), interactional justice is referred to the fairness of the interpersonal treatment that is received during all allocation decision. Behaving interactionally fair includes showing courtesy and respect, and providing justification for decisions. Interactional justice is also referred to the treatment that an individual receives as decisions are made and can be promoted by providing explanations for decisions and delivering the news with sensitivity and respect.

Although there was a study to examine the relationship between OJ and performance evaluation in the Malaysian context, to the best of researcher knowledge less is known regarding the direct relationship between OJ and individuals OCB particularly among the school teachers. As claimed by several researchers (Johnson, Selenta, \& Lord, 2006), employees' perceptions of fairness towards OCB are essential to be investigated since they will ultimately affect the organizational success. A good number of studies have been conducted in Malaysia to examine the effect of OJ on OCB; however it is still under-explored (Hassan \& Noor, 2008). Teachers who hold heavy responsibilities should be fairly evaluated by giving the appropriate rewards and advancement. If teachers' performance is not fairly evaluated, then Malaysia may face a demotivated teaching force (Shaari, Yusof, Jamal Khan, Mei, \& Teong, 2008). Thus, there is a need to empirically test the impact of OJ particularly on teachers' extrinsic CA as well as teachers' intrinsic CA.

Previous researchers suggest that employees who perceive higher levels of justice will demonstrate more OCB. Thus, the violations of justice have been linked to lower level of OCB. Hence, the perceptions of a fair process may result in improving employees' OCB. In addition, the positive career outcomes may enhance individuals' perception towards the process of fairness. Employees will perceive that they have future career opportunity through the fair promotion process. This is because employees are likely to have positive perceptions towards OJ when they receive such desired career outcomes (e.g. NOP, CS). These may imply the pattern of OJ which may able to influence the decisions towards employees' career outcome such NOP and CS. This study assumes that 
teachers should receive career outcomes accordingly to their performance (e.g. OCB). Teachers should be fairly evaluated by the representative of the school. The evaluation should be based on teacher's performance such as OCB. The same approach and information of appraisal process should be applied to all teachers. Teacher who receives the promotion should be seen as a person who can perform well. However, if the evaluation which is made lead to a poor NOP or CS, then the factors of perceived OJ may play some sort of roles in the relationship between performance and career. Given that, OJ would affect the individuals' propensity to engage in OCB and CA. As suggested by Baron and Kenny (1986), a given variable (OJ) may be said to function as a mediator to the extent that it accounts for the relation between the predictor (OCB) and the criterion (CA). Thus, OJ had been tested as a moderator in this study.

Please refer to the proposed conceptualized framework as given in Figure 1.

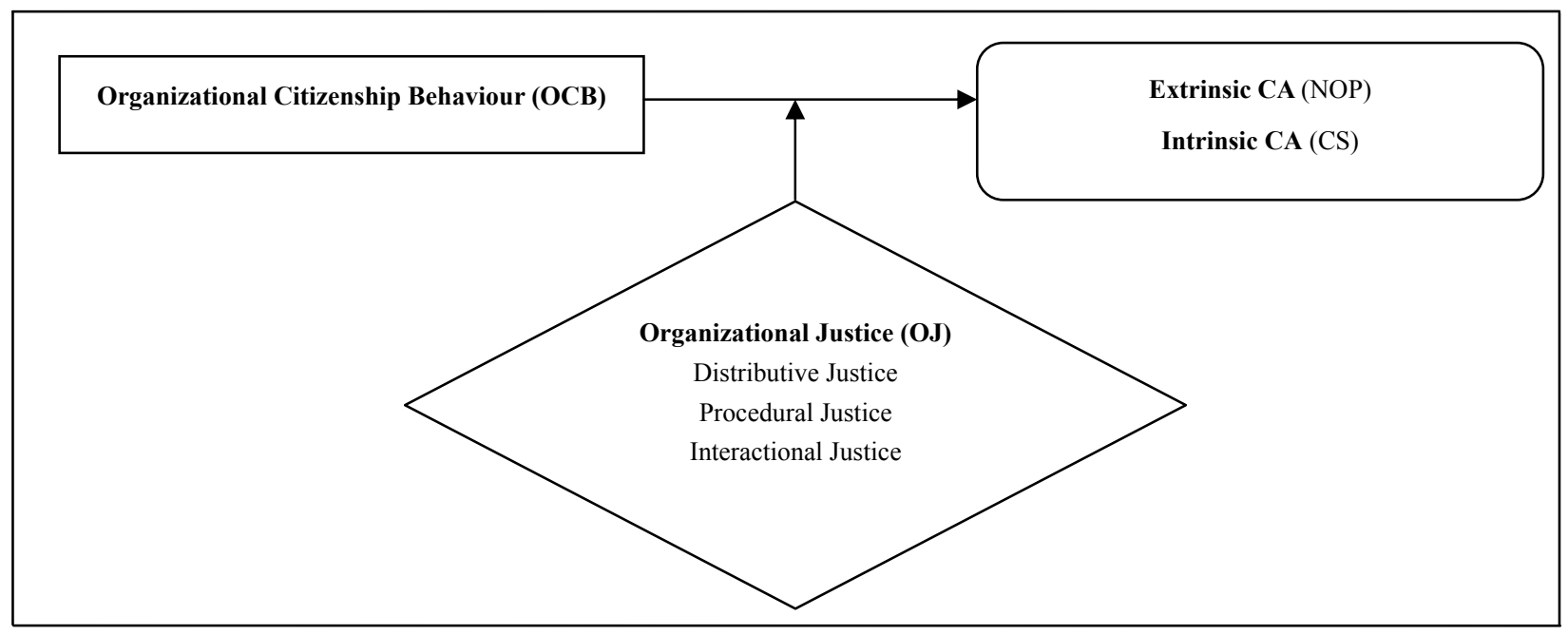

Figure 1. Conceptual framework of the study

\section{Method}

\subsection{Sample and Data Collection Method}

The population of this research includes all teachers from all Primary Schools in one of state located in the northern region of Peninsular Malaysia. The data regarding teachers' NOP, CS, OCB and OJ had been obtained from the perspective of teachers. Focusing on one particular state in doing research among Malaysian teachers is not new in the educational context. The findings of this study may be generalized to the whole country since all teachers in Malaysian need to follow the same procedure towards their promotion. In this study, extrinsic CA is referred to the standard movement of teachers' promotion which has several levels of grade according to the MOE. Hence, it becomes the most practical variable to measure the extrinsic CA of the Malaysian teachers. CS is the most popular measure for the intrinsic component of CA (Hofmans, Dries, \& Pepermans, 2008). Hence it may also appropriate to be tested among teachers in this study. The population size of this study is equal to 17,467 teachers. According to Krejcie and Morgan (1970) as cited by Sekaran (2003), a sample size of 375 teachers is acceptable. However, a bigger sample size is needed to overcome the possibility of non-response problem for a mail survey. The researcher distributed 800 set of questionnaires to the respondents. However, the usable number of the returned questionnaires was only 390. Thus, it was greater than the suggestion of Krejcie and Morgan (1970) as cited by Sekaran (2003).

\subsection{Instrumentation}

There are seven (7) questions have been developed to obtain data regarding the demographic background for all respondents. By using nominal scale, three (3) questions concerning teachers' gender, race and qualification has been developed. The next four (4) questions in the demographic section are based on ratio scale. These questions concerning about the respondents' age, the year of the respondents' first appointment as teachers, the year of respondents' first confirmation as teachers, and the total years of respondents' experience as teachers after they get the confirmation. The tests for demographic background were only conducted for a descriptive analysis. 
As for the extrinsic CA, the nominal scale has been used. In this study, the criterion of promotion refers to three (3) items. The first promotion item concerns with the data regarding teachers' first grade of appointment. The second promotion item asks respondents to state either they has received the promotion or not. The third promotion item asks respondents to tick the highest grade of their attainment. As for the intrinsic CA, the Greenhaus, Parasuraman and Wormley (1990) scale of CS is fully adopted. Next, the instrumentation of teachers' OCB is adopted from DiPaola et al. (2004) measurements. Meanwhile, instrumentation of teachers' OJ which included four (4) dimensional measures as developed by Colquitt (2001) had been first adopted. However, after researcher conducted the factor analysis test the items emerged into three-factor solution (e.g. distributive, procedural, interactional justice). All Likert Scales range from (1) strongly disagrees to (5) strongly agree for intrinsic CS, OCB and OJ.

Table 1 indicates the measures of the study variables used for the questionnaire in the study.

Table 1. Instrumentation of the study variables

\begin{tabular}{cccc}
\hline Study Variables & Number of Items & Source of Scale & Type of Scale \\
\hline Demographics & 3 & & Nominal Scale \\
& 4 & & Ratio Scale \\
Extrinsic CA & 3 & Greenhaus et al. (1990) & Nominal Scale \\
Intrinsic CA & 5 & Dikert Scale \\
OCB & 12 & Colquitt (2001) & Likert Scale \\
OJ & 18 & & Likert Scale \\
\hline
\end{tabular}

\section{Results}

\subsection{Descriptive Statistics}

The findings show that the distribution of gender is higher for females with a total of 298 female respondents (76.4\%). On the other hand, there are 92 male respondents or 23.6 percent out of the total respondents. The age of the respondents show that over half of the respondents $(52.05 \%)$ are in the range age of ' 30 to 39 years' old. There are 28.72 percent of the respondents come in the range age of ' 40 to 49 years' old. Apart from that, 15.13 percent of respondents are in the group of age 'below 30 years' old. The remaining 4.1 percent comes from the category of age which '50 years and above'. Apart from that, only 177 out of 390 respondents $(45.4 \%)$ stated that they already get the promotion. Meanwhile about 54.6 percent or 213 respondents stated that they did not receive the promotion during their career.

\subsection{Means, SD, Minimum and Maximum Value}

The results for the related descriptions based on the questionnaires were reported in Table 2. The mean for all variables are relatively high, with the mean all exceeding the scale mid-point of 3 . Apart from that, it also shows that teachers have the high level of OCB with the mean score at 4.06. Therefore, it confirmed that all respondents already practiced the high level of voluntary behaviour in the working life even though the work activities were not expected by the management representatives.

The dimension of interactional justice appeared as the highest among the other three dimensions of OJ with the score of mean at 4.01. The other two dimensions of OJ namely; distributive justice and procedural justice reported the score of means at 3.81 and 3.70 each. The minimum of 1.00 for distributive justice and 1.25 for procedural justice indicate that some of the respondents are not comfortable with the level of both perceived OJ factors in the primary school context. This could be due to the failure of the management representative in some aspects of work distribution which is consistent to rewards. Also, this could be due to the failure of the management representative in implementing procedures which is consistent to the allocations of teachers' rewards. However, the minimum of 2.25 for interactional justice shows that some of the primary school teachers were already satisfied with the way management representative interacted with them in term of giving information related to teachers' promotion.

The maximum score of 5.00 for $\mathrm{CS}, \mathrm{OCB}$, interactional justice, distributive justice and procedural justice show that some respondents perceived that they are fully committed with the maximum roles for each description of these items. Apart from that, the SD for CS and OCB are at 0.67 and 0.40 each. As for the dimensions of 
perceived OJ, the SD's are 0.55 for interactional justice, 0.64 for distributive justice and 0.58 for procedural justice. These results show that most respondents are close to the mean for all these variables.

Table 2. Means, SD, Minimun and Maximum

\begin{tabular}{cccccc}
\hline Variables & $\mathrm{N}$ & Means & SD & Min & Max \\
\hline Career Satisfaction & 390 & 3.56 & 0.67 & 2.00 & 5.00 \\
OCB & 390 & 4.06 & 0.40 & 2.92 & 5.00 \\
Interactional Justice & 390 & 4.01 & 0.55 & 2.25 & 5.00 \\
Distributive Justice & 390 & 3.81 & 0.64 & 1.00 & 5.00 \\
Procedural Justice & 390 & 3.70 & 0.58 & 1.25 & 5.00 \\
\hline
\end{tabular}

\subsection{Correlations Analyses}

The tests for inter-correlation between all variables are presented in Table 3. Both tests of CA dimension which had been measured in the term of extrinsic (e.g. NOP) and intrinsic (e.g. CS) were presented. Correlations between teachers' CS with OCB and all justice factors showed bivariate relationship among all the variables.

Looking at moderator variables, Table 3 supports the notion that all dimensions of perceived OJ are positively correlated with CS. Specifically, interactional justice is significantly more highly correlated with CS ( $\mathrm{r}=.33$, $\mathrm{p}<.01)$ followed by distributive justice $(\mathrm{r}=.29, \mathrm{p}<.01)$ and procedural justice $(\mathrm{r}=.13, \mathrm{p}<.05)$. However, all dimensions of perceived OJ are not correlated with NOP.

Table 3. Inter-correlation between Variables

\begin{tabular}{lllllll}
\hline Variables & 1 & 2 & 3 & 4 & 5 & 6 \\
\hline Interactional Justice & $-(.94)$ & & & & \\
Distributive Justice & $.28^{* *}$ & $-(.95)$ & & & \\
Procedural Justice & $.27^{* *}$ & .00 & $-(.86)$ & & \\
OCB & $.30^{* *}$ & .09 & .09 & $-(.83)$ & & \\
Number of Promotion & .02 & -.02 & .05 & $.17^{* *}$ & - & \\
Career Satisfaction & $.33^{* *}$ & $.29^{* *}$ & $.13^{*}$ & $.11^{*}$ & $.11^{*}$ & $-(.87)$ \\
\hline$*$ Correlation is significant at the .05 level (2-tailed), ${ }^{* *}$ Correlation is significant at the .01 level $(2$-tailed), \\
$* * *$ Reliabilities are reported in parentheses.
\end{tabular}

\subsection{Regression Analyses}

Result presented that OCB is not significantly related to NOP $(\beta=.11, t=1.70, p=.09)$ as well as CS $(\beta=-.03$, $\mathrm{t}=-.42, \mathrm{p}=.68$ ). Although the results presented that there are no significant relationships between interactional justice $(=.04, \mathrm{t}=-.79, \mathrm{p}=.43)$, distributive justice $(\beta=-.04, \mathrm{t}=-.76, \mathrm{p}=.45)$ and procedural justice $(\beta=.04, \mathrm{t}=.77$, $\mathrm{p}=.45)$ with NOP; however, it shows that there are significant relationships between interactional justice $(\beta=.21$, $\mathrm{t}=4.40, \mathrm{p}=.00)$, distributive justice $(\beta=.28, \mathrm{t}=6.02, \mathrm{p}=.00)$ and procedural justice $(\beta=.13, \mathrm{t}=2.76, \mathrm{p}=.01)$ with $\mathrm{CS}$. The entry of the two-way interactions show that there is a significant interaction between OCB and distributive justice ( $\beta=.19, \mathrm{t}=2.62, \mathrm{p}=.01)$ to teachers' NOP. Apart from that, there is also a significant interaction between OCB and distributive justice ( $\beta=.11, \mathrm{t}=1.66, \mathrm{p}=.01)$ to teachers' CS according to the entry of two-way interaction report. Based on the split regression, OCB appears as an important determinant of extrinsic CA (NOP) for teachers who perceived high distributive justice $(\beta=.27, \mathrm{t}=2.46, \mathrm{p}=.02)$ as compared to teachers who perceived low distributive justice $(\beta=.06, t=.80, p=.43)$. Figure 2 revealed the nature of the interaction between OCB and distributive justice in promotion for teachers who perceived high level of distributive justice and low level of distributive justice. The interaction indicated that, an increase in OCB was associated with an increase in teachers' NOP when teachers perceived high level of distributive justice $(\beta=.27, t=2.46, p=.02)$. Among teachers who perceived low distributive justice, OCB seemed to be unrelated to NOP $(\beta=.06, t=.80, p=.43)$. Therefore, the line representing teachers who perceived high distributive justice is more positively sloped than the line 
representing teachers who perceived low distributive justice.

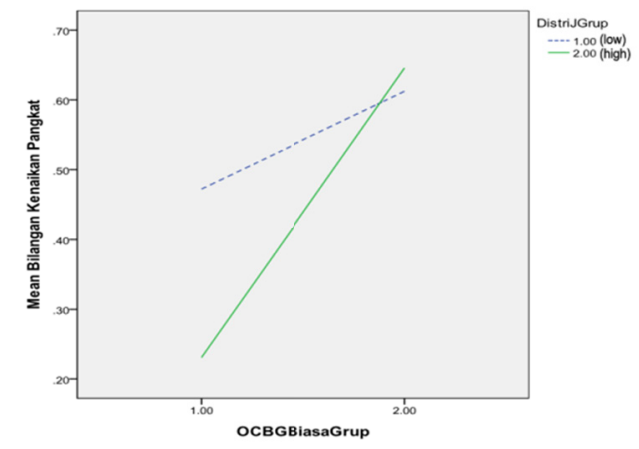

Figure 2. Interaction Plot between OCB and Distributive Justice on Teachers' NOP

Apart from that, based on the split regression, OCB is also an important determinant of intrinsic CA (CS) for teachers who perceived high distributive justice $(\beta=.27, \mathrm{t}=2.44, \mathrm{p}=.02)$ as compared to teachers who perceived low distributive justice $(\beta=-.16, \mathrm{t}=-2.06, \mathrm{p}=.04)$. Figure 3 presented the nature of the interaction between OCB and distributive justice in CS, specifically for teachers in the group who perceived high level of distributive justice and low level of distributive justice. The interactions indicated that, an increase in OCB was associated with an increase in teachers' CS when teachers perceived high level of distributive justice $(\beta=.27, t=2.44, p=.02)$. However, among teachers who perceived low distributive justice, OCB seemed to be unrelated to CS ( $\beta=-.16$, $\mathrm{t}=-2.06, \mathrm{p}=.04)$. Therefore, the line representing teachers who perceived high distributive justice is more positively sloped than the line representing teachers who perceived low distributive justice.

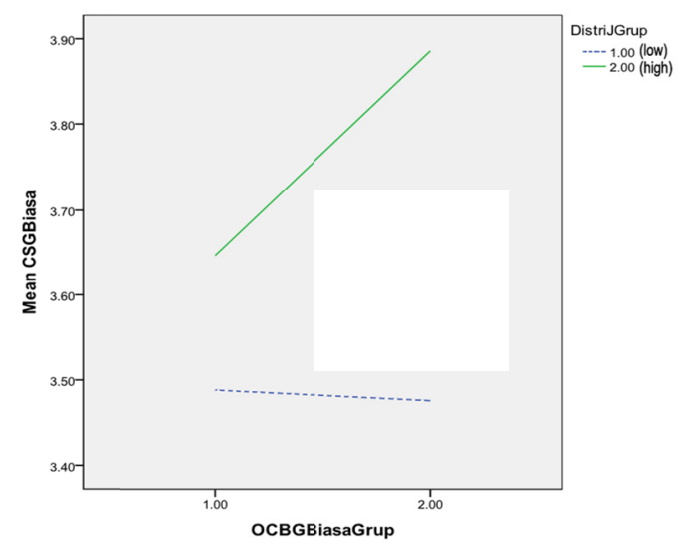

Figure 3. Interaction Plot between OCB and Distributive Justice on Teachers' CS

\section{Discussions and Conclusions}

There was no significant relationship between teachers' OCB and teachers' extrinsic CA in term of NOP. Similarly, there was also no significant relationship between teachers' OCB and teachers' intrinsic CA in term of CS. Although Bergeron (2004) concludes that OCB may take time to show it benefits towards an individual, the benefits of OCB did not reflected on teachers' rewards in the Malaysian educational context. In this study, half of the respondents (51.02 percent) had less than 10 years of teaching experience. Therefore, they are considered new in servicing the educational institutions. Hence, the benefits for them in practicing OCB; particularly towards the enhancement of the NOP could not be seen in a short period of time. According to the time based promotion (one of the career path for teachers under MOE), teachers should at least have 10 years of teaching experience and fulfill several conditions in order to make them entitle to apply for higher position. Thus, it may present that OCB will be a threat to the Malaysian teachers who are still new in their appointment. This was inconsistent from the findings of Bergeron (2005) who found the relationship between OCB and CA among UK academician (e.g. Associates Professor, Full Professor rank) who already enjoy the full-time tenured or tenure-track in servicing their university. Therefore, more time is needed for the Malaysian teachers to see the 
positive effects of OCB, particularly towards their career outcomes such as promotion. Hence, OCB could be a behaviour that generates frustration to those who are still new in the teaching profession. In addition, OCB in teachers is related to the school's image and a cooperative, collegial school climate (Oplatka, 2009). This may be due to the reason that teachers in Malaysia do not expect that OCB is something that may relate to their personal career expectation particularly towards their NOP or CS levels. Therefore, OCB has been displayed without the expectation to gain any benefits, particularly towards their personal convenience such as NOP or CS. However, OCB has been performed in order to help the school to enhance its performance. Thus, OCB could be a behaviour that generates suffering towards teachers' own benefit at the new stage in the educational sector.

In term of the moderator effect, it was found that all factors of justice are significantly related to teachers' CS but not to teachers' NOP. Therefore, all these justice factors are the set of predictor of teachers' CS in the Malaysian educational context. Therefore, these findings are in line with the findings of Bagdadli, Roberson and Poaletti (2006) who suggest that $\mathrm{OJ}$ in the factors of distributive justice and procedural justice are significantly associated with CS. In addition, these findings were also consistent with the findings of Jamali and Nejati (2009) who found that the enhancement of the interactional justice factor can decrease the barriers for CA among academicians in the Iranian society.

Apart from that, this study found that perceived OJ in the school context has such unique interacting effects based on its factor towards both types of teachers' CA. Briefly, this study found that there was significant interaction between OCB and perceived distributive justice to teachers' NOP $(\beta=.19, p=.01)$. Similarly, this study also found that there was significant interaction between OCB and perceived distributive justice to teachers' CS $(\beta=.11, p=.01)$. Given that, this study is consistent with the study of Hemdi and Nasurdin (2008) who indicate that distributive justice perception is significantly related to OCB.

This study suggests that MOE should prescribe the activities that involved teachers with voluntary behaviour that may be considered by the managerial side towards the process of teachers' performance evaluation as well as the process of teachers' promotion. In addition, MOE should officially announce the list of performances those are expected from the ministry. Hence, these kinds of performances should be displayed by all primary school teachers who are appointed under MOE. The school representatives should increase the level of distributive justice in the educational context. Specifically, MOE is advised to get the feedback from teachers especially on activities that engage them with the allocation of works that will create the positive impact on their expected CA such as promotion. Therefore, the appearance of distributive justice can be enhanced in the primary school context. Next, MOE is advised to formally inform the school representatives that they are responsible to let all teachers know about the information that relate teachers with the process promotion. For example, Headmasters could conduct a handholding session in order to guide teachers on how to fill in the promotion form. Therefore, the appearance of interactional justice can be enhanced in the primary school context. Finally, MOE should encourage the school representatives to gather inputs from all categories of teachers. Thus, the practice of procedural justice can be improved in the school context.

\section{References}

Akhtar, S. (2010). Causal attributions of career success across genders: A perspective of private sector organizations. World Applied Sciences Journal, 11(6), 646-652.

Bagdadli, S., Roberson, Q., \& Paoletti, F. (2006). The mediating role of procedural justice in responses to promotion decisions. Journal of Business and Psychology, 21(1), 83-102. http://dx.doi.org/10.1007/s10869005-9017-y

Ballout, H. I. (2009). Career commitment and career success: moderating role of self-efficacy. Career Development International, 14(7), 655-670. http://dx.doi.org/10.1108/13620430911005708

Baron, R. M., \& Kenny, D. A. (1986). The moderator-mediator variable distinction in Social Psychological research: Conceptual, strategic, and statistical considerations. Journal of Personality and Social Psychology, 51, 1173-1182. http://dx.doi.org/10.1037/0022-3514.51.6.1173

Bergeron, D. M. (2005). Organizational citizenship behaviour: A negative relationship to career outcomes? Academy of Management Best Conference Paper. OB: Q2.

Bies, R. J., \& Moag, J. S. (1986). Interactional justice: Communication criteria of fairness. Research on Negotiation in Organizations, 1, 43-55.

Carmeli, A., Shalom, R., \& Weisberg, J. (2007). Consideration in organizational CA: What really matters. Personal Review, 35(2), 190-205. http://dx.doi.org/10.1108/00483480710726109 
Christensen, R. K., \& Whiting, S. W. (2009). The role of task performance and organizational citizenship behaviour in performance appraisals across Sectors: Exploring the role of public service motivation. Paper presented at the International Public Service Motivation Research Conference, Bloomington, Indiana.

Colquitt, J. A. (2001). On the dimensionality of OJ: A construct validation of a measure. Journal of Applied Psychology, 86, 386-400. http://dx.doi.org/10.1037/0021-9010.86.3.386

Cropanzano, R. (1993). Justice in the workplace: Approaching fairness in human resource management. Lawrence Erlbaum, Hillsdale, NJ.

DiPaola, M. F., \& Hoy, W. K. (2004). Organizational citizenship of faculty and achievement of high school students. The High School Journal, 88, 16-45.

DiPaola, M. F., \& Tschannen-Moran, M. (2001). Organizational citizenship behaviour in school and its relationship to school climate. Journal of School Leadership, 11, 424-447.

DiPaola, M. F., Tarter, J. C., \& Hoy, W. K. (2004). Measuring organizational citizenship in Schools: The OCB Scale. Information Age Publishing, Charlotte, NC.

Folger, R., \& Greenberg, J. (1985). Procedural justice: An interpretational analysis of personnel systems. Research in Personnel and Human Resources Management, 3, 141-183.

Greenberg, J. (1987). Reactions to procedural injustice in payment distributions: Do the ends justify the means? Journal of Applied Psychology, 72, 55-61. http://dx.doi.org/10.1037/0021-9010.72.1.55

Greenberg, J. (1990). Employee theft as a reaction to underpayment inequity: The hidden cost of pay cuts. Journal of Applied Psychology, 75(5), 561-568. http://dx.doi.org/10.1037/0021-9010.75.5.561

Greenhaus, J. H., Parasuraman, S., \& Wormley, W. (1990). The effect of race on organizational experiences, job performance evaluation, and career outcomes. Academy of Management Journal, 33(1), 64-86. http://dx.doi.org/10.2307/256352

Grubb, T. (2007). Performance appraisal reappraised: It's not all positive. Journal of Human Resource Education, $1(1), 1-22$.

Hannam, R. L., \& Jimmieson, N. L. (2002). The relationship between extra-role behaviours and job burnout for primary school teachers: A preliminary model and development of an organizational citizenship behaviour scale. In W. Shilton, \& J. Ruth (Eds.), Abstracts of Papers to be Presented at the AARE 2002 International Education Research Conference. 2002 Annual Conference of the Australian Association for Research, Brisbane, (1-17). 15 December 2002.

Hassan, A., \& Noor, K. M. (2008). OJ and extra-role behaviour: Examining the relationship in the Malaysian cultural context. IIUM Journal of Economics and Management, 16(2), 187-208.

Hemdi, M. A., \& Nasurdin, A. M. (2008). Investigating the influence of OJ on hotel employees' OCB intentions and turnover intentions. Journal of Human Resources in Hospitality and Tourism, 7(1), 1-23. http://dx.doi.org/10.1300/J171v07n01_01

Hofmans, J., Dries, N., \& Pepermans, R. (2008). The CS scale: Response bias among men and women. Journal of Vocational Behaviour, 73, 397-403. http://dx.doi.org/10.1016/j.jvb.2008.08.001

Hsieh Y. M., \& Hsieh, A. T. (2003). Does job standardization increase job burnout? International Journal of Manpower, 24(5), 590-614. http://dx.doi.org/10.1108/01437720310491107

Jamali, R., \& Nejati, M. (2009). Women's career progression barriers and OJ: A study of Iranian society. Business Strategies Series, 10(5), 311-328. http://dx.doi.org/10.1108/17515630910989204

Johnson, R. E., Selenta, C., \& Lord, R. G. (2006). When OJ and the self-concept meet: Consequences for the organization and its members. Organizational Behaviour and Human Decision Processes, 99, 175-201. http://dx.doi.org/10.1016/j.obhdp.2005.07.005

Karatepe, O. M., \& Uludag, O. (2008). Roles stress, burnout and their effects on frontline hotel employees' job performance: Evidence from Northern Cyprus. International Journal of Tourism Research, 10(1), 111-126. http://dx.doi.org/10.1002/jtr.645

Khalid, S. A., \& Ali, H. (2005). Self and superior-ratings of organizational citizenship behaviour: Are there differences in the source of ratings? Problem and Perspectives in Management, 4, 147-153.

Leventhal, G. S. (1980). What should be done with equity theory? In K. J. Gergen, M. S. Greenberg, \& R. H. Willis (Eds.), Social Exchanges: Advances in Theory and Research (pp. 27-55). New York: Plenum. 
http://dx.doi.org/10.1007/978-1-4613-3087-5_2

Leventhal, G. S., Karuza, J., \& Fry, W. R. (1980). Beyond fairness: a theory of allocation preferences. In G. Mikula (Eds.), Justice and Social Interaction (pp. 167-218). Springer-Verlag, New York, NY.

Malakolunthu, S., \& Malek, N. (2008). Sistem penilaian guru: Realiti dan cabaran. Masalah Pendidikan, 31(2). (Non-ISI/Non-SCOPUS Cited Publication).

Metro, H. (2010, September 30). Guru Sudah Jadi Kerani.

Metz, I., \& Tharenou, P. (2001). Women's CA: The relative contribution of human and social capital. Group \& Organization Management, 26, 312-342. http://dx.doi.org/10.1177/1059601101263005

Mohd Shahrom, S. (2009). Looking back and looking forward: A case study of Malaysian teachers. The $2^{\text {nd }}$ International Conference of Teaching and Learning (ICTL 2009) INTI University College, Malaysia.

Muda, M. S., \& Omar, N. W. (2006). Model peramal kepuasan kerja pegawai perkhidmatan pendidikan di komuniti pesisir Terengganu. International Journal of Management Studies, 13(Special Issue), 123-142.

Okurame, D. E., \& Balogun, S. K. (2005). Role of informal mentoring in the career success of first-line bank managers: A Nigerian case study. Career Development International, 10(6-7), 512-521.

Oplatka, I. (2009). Organizational citizenship behaviour in teaching: The consequences for teachers, pupils and the school. International Journal of Education Management, 23(5), 375-389. http://dx.doi.org/10.1108/09513540910970476

Pelan Laluan Kerjaya Pegawai Perkhidmatan Pendidikan. (2009). Kementerian Pelajaran Malaysia (MOE).

Podsakoff, P. M., MacKenzie, S. B., Paine, J. B., \& Bachrach, D. G. (2000). Organizational citizenship behaviours: A critical review of the theoretical and empirical literature and suggestions for future research. Journal of Management, 26, 513-563. http://dx.doi.org/10.1177/014920630002600307

Shaari, A. S., Yusof, A. A., Jamal Khan, M. K., Mei, T. S., \& Teong, L. K. (2008). Keadilan penilaian prestasi dalam kalangan guru dan hubungannya dengan motivasi kerja dan prestasi akademik sekolah. International Journal of Management Studies (IJMS), 15, 159-176.

Yee, C. C., \& Chen, Y. Y. (2009). Performance Appraisal System using Multifactorial Evaluation Model. In Proceedings of World Academy of Science, Engineering and Technology 53, May 2009, Tokyo, Japan.

Zainal, S. R. M. (2009). The effects of upward influence tactics towards CA: A study among manufacturing employees in Northern States. Malaysia Labour Review, 3(1), 98-109.

Zhao, W., \& Zhou, X. (2008). Intra-organizational CA and voluntary in a multinational bank in Taiwan. Career Development International, 13, 402-424. http://dx.doi.org/10.1108/13620430810891446

\section{Copyrights}

Copyright for this article is retained by the author (s), with first publication rights granted to the journal.

This is an open-access article distributed under the terms and conditions of the Creative Commons Attribution license (http://creativecommons.org/licenses/by/3.0/). 